\title{
AN EMPIRICAL EVIDENCE OF MISALIGNMENT EXCHANGE RATE IN MALAYSIA USING BEER MODEL
}

\author{
J. M. Shukri ${ }^{*}$, Muzafar Shah Habibullah ${ }^{2}$ \\ ${ }^{1}$ Faculty of Business and Management, Universiti Teknologi MARA, 23000 Dungun, Terengganu, Ma- \\ laysia \\ ${ }^{2}$ Faculty of Economics and Management, Universiti Putra Malaysia, 43400 Serdang, Selangor, Ma- \\ laysia \\ *mohdshukri@tganu.uitm.edu.my
}

\begin{abstract}
As a small, open economy and newly industrialised country, Malaysia is also experiencing misalignment in its currency exchange. Hence, the aims of this paper is to investigate the exchange rate movement using BEER model. This paper adopts the bound testing and autoregressive distributed lag (ARDL) to examine the cointegration among variables for the period of 1970 to 2012. The results suggest that productivity differential, net foreign assets, terms of trade and trade liberalization play important roles in influencing exchange rate movement in Malaysia. The results also show that a misalignment of exchange rate is at a small percentage and stable. Besides that, the predictive power of BEER model shows a small root mean square error, thus revealing that the model is likely fit the data very close throughout the period and tracks the actual exchange rate to get a considerable number of turning points correct.
\end{abstract}

Keywords: Behavior Equilibrium Exchange Rate (BEER), Misalignment of Exchange Rate, Bound Testing, Autoregressive Distributed Lag (ARDL), Predictive Power, Root Mean Square Error (RMSE

\section{INTRODUCTION}

The issues of international trade and the misalignment of exchange rates are often debated over the past few decades (Lee, 2005; Coudert \& Couharde, 2007; You \& Sarantis, 2008; Koske, 2008; Chin et al., 2009; Naseem et al., 2008; Tsen Wong, 2013). Malaysian currency is also believed to experience a misalignment of exchange rates, due the fact that this country is newly industrialized and implemented its open economy policy since its independence in 1957. According to Koske (2008) and Maeso-Fernandez et al. (2006), the open economy policy in a country will involve high transactions of foreign currencies and thus creates the phenomena of disequilibrium of currency. As a small country, this phenomenon might worsened the situation (Corsetti et al., 1999). Generally, the misalignment of exchange rates is the difference between the real exchange rate of a country and its equilibrium level, thus may cause national currency to be undervalued or overvalued (Naseem et al., 2008; Tsen Wong, 2013).

The impact of misalignment of currency to the economy is quite huge (Daniel \& VanHoose, 2005). Therefore, the economist, policymakers and others currency players (such as exporters-importers, money changer, etc.) should be more concerned with this matter. The issues of Asian's financial crisis in 1997-1998 which started in Thailand and the sub-prime/financial crisis in the United State and Europe in 2007-2009 have motivated many researchers and economists in doing research about the impact of misalignment exchange rate to the economy. For instance, the study conducted by Naseem et al. (2008) suggests that the exchange rate misalignment is important determinants in inspiring Malaysian import flows, whilst Tsen Wong (2013), Daniel and VanHoose (2005) found that exchange rate misalignment will cause bad effect to the economic growth. However, Rodrik (2008) provides evidence that misalignment of the currency able stimulates economic growth. Meanwhile, the study conducted by Chin (2005) and Lee (2005) found that there is little evidence of exchange rate misalignment is found to exist in the second quarter of 1997. How to measure the equilibrium exchange rate and its misalignment? What are the causes that might generate misalignment of exchange rate? And, does the exchange rates model really represent real exchange rate behavior in Malaysia? 
Firstly, the traditional theory of exchange rate behavior is the Purchasing Power Parity (henceforth PPP) and the Law of One Price (henceforth LOP) introduced by Gustaz Cassel in 1918. Generally, the absolute version of PPP/LOP can be expressed as:

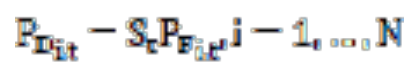

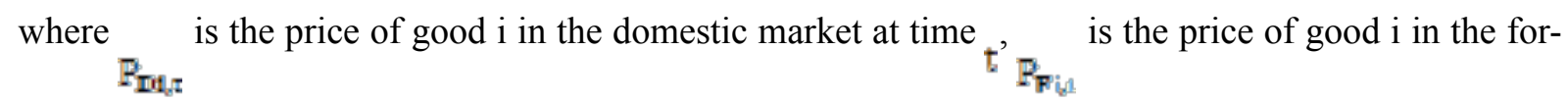
eign market (in US dollars) and ${ }_{S_{\tau}}$ is the nominal exchange rate of the foreign currency (the price in domestic currency-per-currency exchange rate of the dollar), sub-index i denote the type of product (which ranges from 1 to ${ }_{\mathrm{N}}$ ), sub-index ${ }_{\mathrm{t}}$ denotes time and ${ }_{\mathrm{N}}$ denotes the number of individual products consumed and produced in domestic and foreign currency. The absolute PPP/LOP will hold for all goods and services if there are no restriction on tradable goods and services across the border. Therefore, the spot exchange rate can be expressed by rearranging the absolute PPP/LOP as below:

\section{$\$_{\mathrm{s}}-\mathrm{P}_{\mathrm{DA}, \mathrm{g}} / \mathrm{P}_{\mathrm{F} 1 \mathrm{x}}$}

Equation (2) expresses that the nominal exchange rate (spot rate) between two countries is determined by the domestic and the foreign general price level. In other words, the bilateral spot exchange rate should be equal to the ratio of the general price levels of the two countries. However, the previous study argued that these theory is a very crude model and unable to predict well especially in the shortrun (Lee, 2005; Chin, 2005; Clark \& MacDonald, 1999; Cline \& Williamson, 2008; Berger \& Kempa, 2012). Furthermore, the PPP/LOP models do not take into account the real factors such as net assets levels and balance of payments positions which makes it difficult to adopt this models. Another concern that the PPP/LOP models cannot indicate real competitiveness due to productivity gaps which creates price gaps between emerging and developed countries. Figure 1 describes the theory of PPP/ LOP and the misalignment of exchange rate in Malaysia.

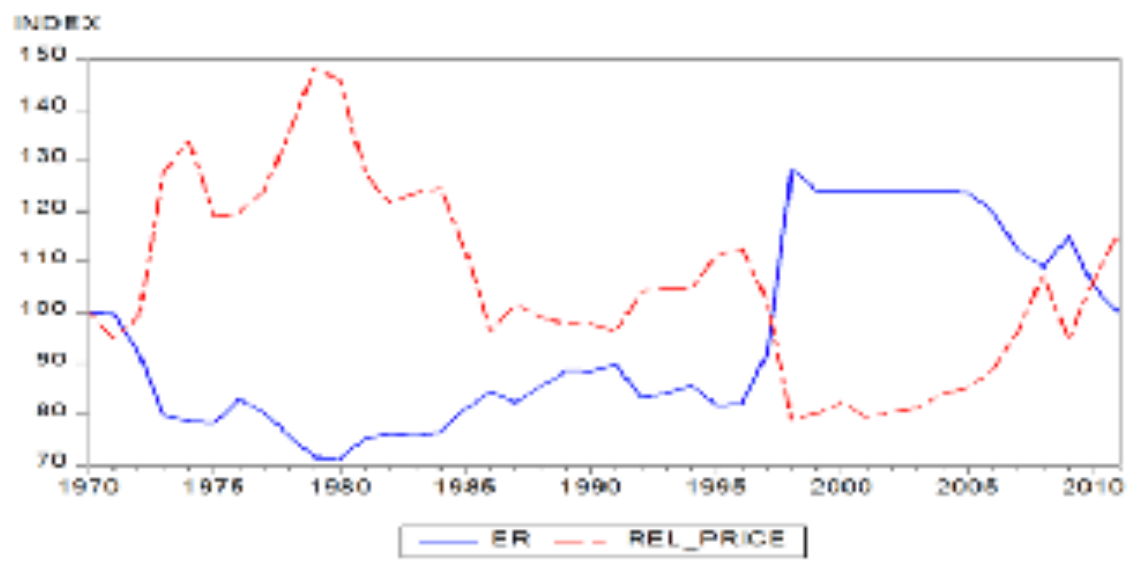

Figure 1.

Purchasing Power Parity, Malaysia/United States, 1970-2012 (Source: World Development Indicator (WDI), United Nation Statistical Division and authors' computations. Note: Index 1970 = 100)

Secondly, many studies provide evidence that the macroeconomic fundamental factors such as term of trade (Naseem et al., 2008; Kębłowski \& Welfe, 2010; Balázs \& Amina, 2003), trade liberalization 
(Maeso-Fernandez et al., 2006; Balázs \& Amina, 2003), real interest rate (Lee, 2005; Naseem et al., 2008; Chin, 2005; Berger \& Kempa, 2012), productivity differential (Naseem et al., 2008; BénassyQuéré et al., 2011; Mohd Sidek \& Yusoff, 2009), net foreign assets (Bénassy-Quéré et al., 2011; López-Villavicencio, 2006; Sahminan, 2005) and government spending (Naseem et al., 2008; MaesoFernandez et al., 2006; Mohd Sidek \& Yusoff, 2009) might influence the equilibrium exchange rate, rather than price level. Figure 2 clearly indicates that there are upward trends (correlation) in all macroeconomics fundamental variables except government spending.

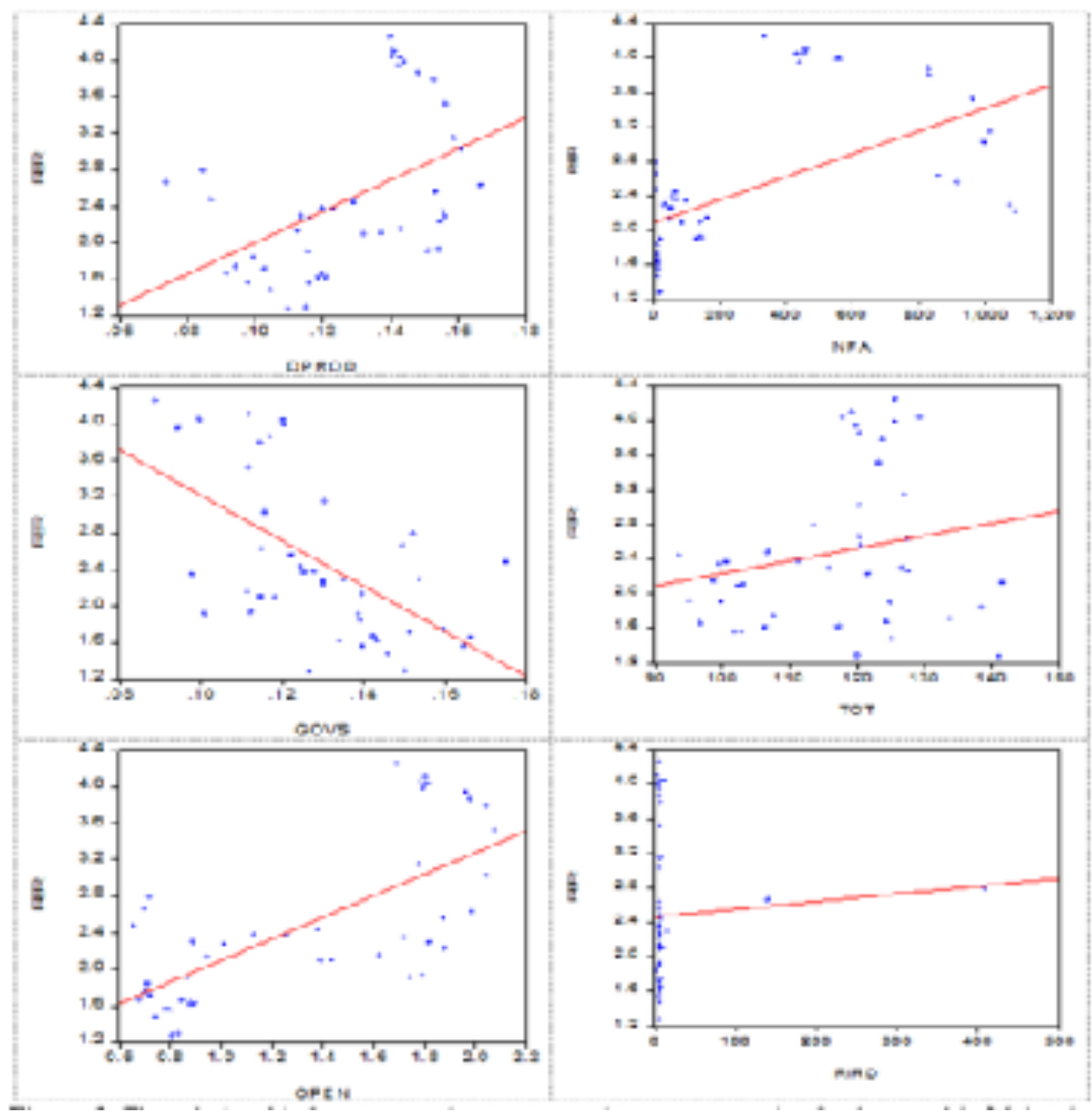

Figure 2. The relationship between exchange rate and macroeconomics fundamental in Malaysia, 1970-2012 (Sources: United Nation Statistic Department (UNSD), Penn World Table (PWT), World Development Indicators (WDI), United Nations Conference on Trade and Development (UNCTAD). Notes: RER - real exchange rate; DPROD - productivity differential; NFA - net foreign assets; GOVS - government spending; TOT - terms of trade; OPEN - trade liberalization (proxy of openness) and RID - real interest rate differential)

Thirdly, previous researcher such as Lee (2005), Tsen Wong (2013), Chin (2005) and Habibullah (1999) employ the forecasting evaluation to determine the predictive power of the model's estimator. According to Hendry and Clements (2003), a good model produces a good forecast and therefore, it is able to represent the best economic behavior. Besides that, the study conducted by Meese and Rogoff (1981) proposed the in-sample and out-of-sample forecast by measuring Root Mean Square Error (RMSE) to evaluate the predictive power of the economic models.

Previous studies such as Lee (2005), Chin et al. (2009), Chin (2005) and Chin et al. (2007) employ methodology proposed by Meese and Rogoff (1981) to determine the predictive power of exchange 
rate model namely Monetary model for ASEAN-5, including Malaysia. Whilst, another study conducted by Tsen Wong (2013) employed the similar methodology to determine the best models to estimate equilibrium real exchange rate in Malaysia. Therefore, the purpose of this paper is to estimate the equilibrium exchange rates using BEER model and to identify the macroeconomic fundamentals as determinants of the exchange rate for Malaysia. This paper will also produce the predictive power of BEER model. To our best knowledge, this is the first study that produces the predictability in estimating equilibrium exchange rates for Malaysia using BEER model.

This paper is organized as follows. The overview of study, published empirical and theoretical literature on equilibrium exchange rate in Malaysia is summarized in Section 1. Research Methodology is explained in Section 2. Section 3 presents the results and discussion. Finally, Section 4 will summarize the main findings and conclude with some policy implications, as well as suggestions for further studies.

\section{METHODOLOGY}

\section{Theoretical Framework}

The BEER model which was associated by Clark \& MacDonald (1999) is a general model of exchange rate and not based on any specific model of exchange rate. According to Driver and Westaway (2013), the advantage of this model is that it can show the movements in real exchange rate over time which are short-run, medium-run and long-run equilibrium level. Another advantage of BEER is the model also does not require that the fundamental factors and the real equilibrium exchange rate be stationary Driver and Westaway (2013).

The real uncovered interest parity (UIP) condition is a starting point in order to estimate real equilibrium exchange rate by this model. The UIP excludes forward markets activity by the participants to transfer foreign exchange rate in its system of transactions (for a comprehensive discussion, see Clark \& MacDonald (1999), Driver \& Westaway (2013) and Égert et al. (2006). The BEER model can be expressed as following equation:

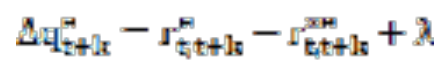

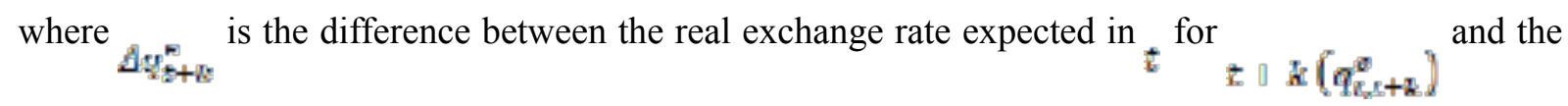

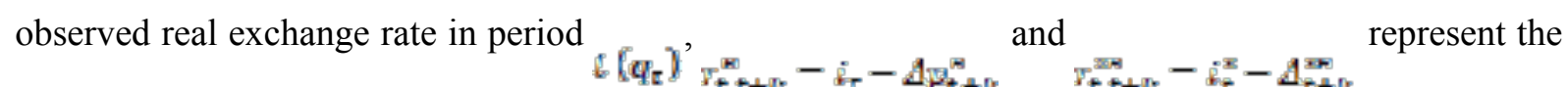
domestic and foreign ex ante real interest rate and ${ }_{\lambda_{r}}$ is a measure of the risk premium. By rearranging Equation (3), the real exchange rate can be expressed as below:

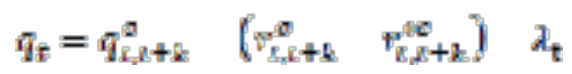

A rise in is said to be an appreciation to the general real exchange rate, whilst the fall in is said to be a depreciation to the general real exchange rate (MacDonald, 1999). If is interpreted as the 'long-run' or systematic, component of the real exchange rate, it can be assumed to be the outcome of the expected values of the fundamentals and can be replaced by as in Equation (4), 


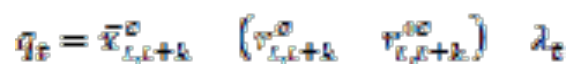

where $\lambda_{s}$ is the time-varying risk premium. With rational expectations imposed, Equation (5) can be rewritten as:

$G_{r}-\bar{x}_{r}-\left(r_{r}-r_{t}^{x}\right)$

therefore, the ${\overline{x_{x}}}_{\text {in }}$ is given the equation function as below:

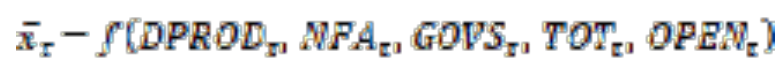

By rearranging the Equation (6) and (7), therefore, the estimation model for BEER in this paper can be shown by the following equation:

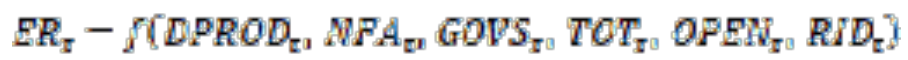

where ${ }_{E R_{s}}$ is real exchange rate in BEER model and ${ }_{R I D_{r}}$ is real interest rate differential. Equation (8) can be rewritten as following equation:

$L E R_{s}-\theta_{0}+\theta_{1} L D P R O D_{\mathrm{r}}+\theta_{2} L N F A_{\mathrm{r}}+\theta_{3} L G O V S_{\mathrm{r}}+\theta_{4} L T C T_{\mathrm{s}}+\theta_{5} L O P E N_{\mathrm{r}}+\theta_{6} L R I D_{\mathrm{r}}+w_{\mathrm{r}}$

where ${ }_{L E R_{y}{ }^{\prime}{ }^{6}}$ and ${ }_{y}$ denotes as real exchange rate, vectors of coefficient and disturbances term respectively. Any deviation from equilibrium is reflected in the ${ }_{\mathbb{F}_{r}}$ term which includes both short-term influences and random disturbances; and ${ }_{L D P R O D_{x}}$ is productivity differential; ${ }_{L N F A_{x}}$ is net foreign

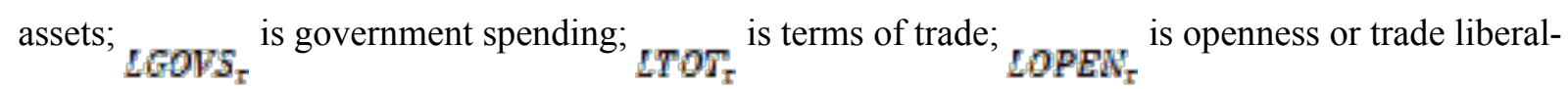
ization policy and ${ }_{L R I D_{r}}$ is real interest rate differential. All variables are in natural logarithm. We ex-

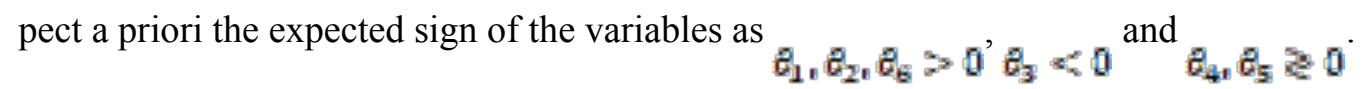

\section{Bound Testing}

This paper adopted the autoregressive distributed lag (ARDL) model approach to examine the long run relationships (or cointegration) among variables and the dynamic effect within variables in the short run. A specified 'unrestricted error correction model' (UECM) of the estimator model for dynamic data is then given to determine the long-run relationships. Further analysis can be conducted to examine whether

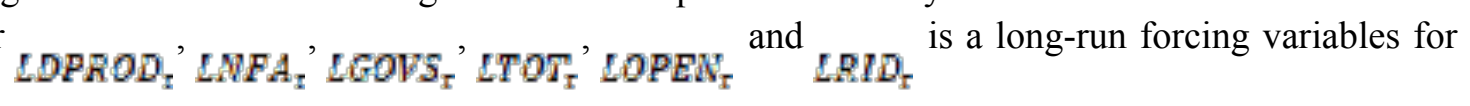

Therefore, Equation (9) can be rewritten as the following equation: 


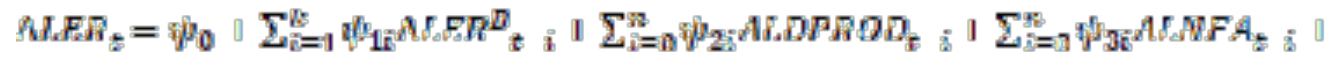

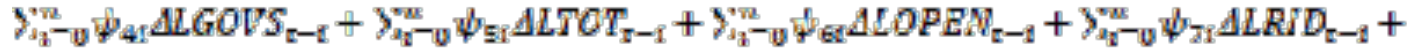

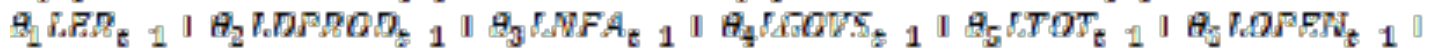
$0_{7} L R W w_{x-1}+\epsilon_{1}$

where ${ }_{C}$ is disturbance term. By using the standard F-test, the null hypothesis of non-existence of the long-run relationship is defined as

$$
H_{0}: \theta_{1}-\theta_{2}-\theta_{3}-\theta_{4}-\theta_{5}-\theta_{6}-\theta_{2}-0
$$

against

\section{$H_{\mathrm{a}}: \theta_{1}+\theta_{2}+\theta_{3}+\theta_{4}+\theta_{5}+\theta_{3}+\theta_{2}+0^{\circ}$}

According to (Pesaran et al., 2001), the bounds F-test must be valid to ensure that there is no serial correlation by employing LM statistics for testing the hypothesis of no serial correlation against orders 1 and 2. Meanwhile, the Schwartz-Bayesian Criterion (SBS) is used to determine the optimal lag length.

\section{Long-Run Estimation Model (ARDL)}

Once cointegration is established, the long-run equation presented in Equation (9) can be derived from Equation (10) and can be expressed as following equation:

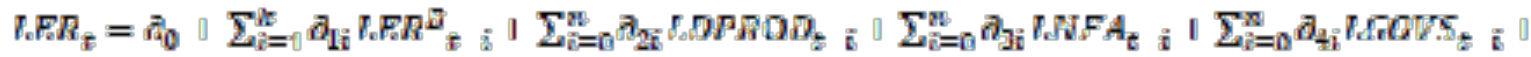

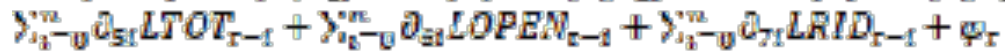

when we have and

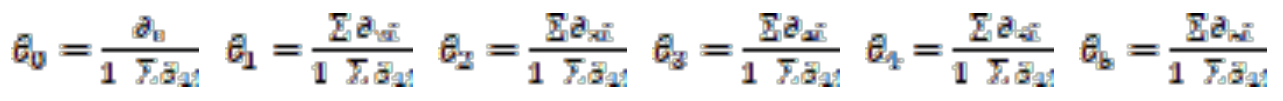

$\epsilon_{6}=\frac{g a_{x}}{1 \bar{y}_{2} \Xi_{2}}$

\section{Short-Run Model}

The ARDL specification of the short-run dynamics can be derived by constructing a 'restricted error correction model' (RECM) as a following equation:

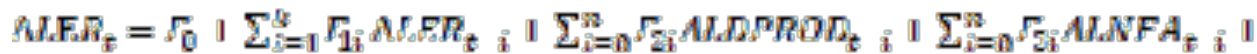

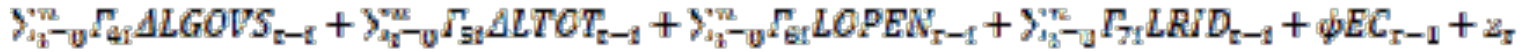

where $E C_{\mathrm{r}-\perp}$ is the lagged residual from cointegration (the long-run equation) between dependent and independent variables in level derived from ARDL model (Pesaran et al., 2001). The null hypothesis for $E C_{\mathrm{r}-\mathbb{R}}$ for different numbers of regressors $\left(_{k}\right)$ can be expressed as $H_{0}: \Phi_{-0}$, against of $H_{\mathrm{a}:}: \emptyset^{\mathrm{s}}$. The significant of the ${ }_{\phi}$ shows that long-run relationship exists, thus supporting the result

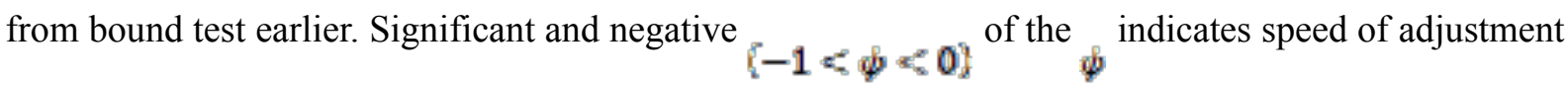
and the deviation from equilibrium. The negative value for 's suggest that the model is stable and any 
deviation from equilibrium will be corrected in the long-run. Thus, the error correction model for BEER can be expressed by following equation:

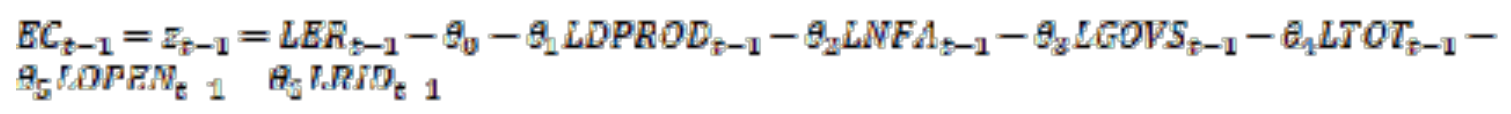

This study is using annual data for Malaysia starting from 1970 until 2012. The real exchange rate ( LER ) is the nominal exchange rate that has been adjusted for the inflation differential between two

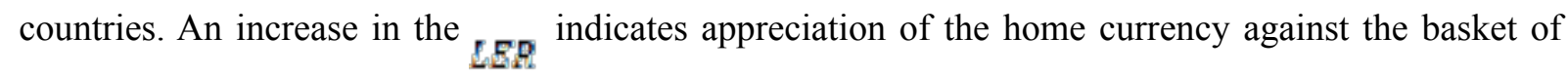
currencies of trading partners.

LDPROD is the productivity differential between Malaysia and United State (US) calculated as the ratio of the real GDP (constant US\$) over employment (million) in both countries. The higher the productivity differential in the home country relative to the foreign country is reflected in increases in the price level, causing a real appreciation of the home currency (Driver \& Westaway, 2013; Égert et al., 2006). The ${ }_{\text {ENFA }}$ is the net foreign asset calculated as the ratio of the domestic country's net foreign asset position to nominal gross domestic product (GDP). The higher capital inflow into a country increased net foreign assets and GDP which led to export growth, thus requiring the currency to appreciate. Meanwhile, ${ }_{\text {EPID }}$ is the domestic and foreign real interest rate differential. Pattichis et al. (2007) stated that increasing the real interest rate differential may reflect higher capital productivity, leading to a capital inflow and subsequently appreciation of the real exchange rate. Thus, productivity and interest rate differential, and net foreign assets are expected to be positively related to the exchange rate.

The EGOVS is the total government consumption over nominal GDP as a proxy for non-tradable government consumption. Following Égert et al. (2006), the government spending is general government final consumption expenditure (current US\$) over nominal GDP (current US\$) as a proxy for nontradable government consumption. Therefore, cGovs is expected to be positively related to the exchange rate. The ETOT $_{\text {is }}$ ise ratio of domestic export unit value (export price in US Dollars) to import value (import price in US dollars) as a proportion of the equivalent effective foreign ratio. The larger revenues from exports will affect to the increasing in terms of trade (income effect), thereby results in shifting away foreign demand for domestic exports (substitution effect). If income effects of the terms of trade dominate its substitution effects, an improvement in terms of trade results in exchange rate appreciation, and vice versa. Lastly, LOPEN $_{\text {is }}$ is the ratio of the sum of exports and imports relative to real GDP. The ${ }_{\text {COPEN }}$ is a proxy for trade liberalization of the country. The reduction of tariff increases the level of trade in the current account (and vice versa), therefore exchange rate will appreciate (and vice versa). ETOT and ${ }_{\text {LOPEN }}$ are expected to be ambiguous related to the exchange rate.

All the data can be obtained from United Nation Statistic Department (UNSD), United Nations Conference on Trade and Development (UNCTAD), World Bank's World Development Indicators (WDI) and Penn World Table (PWT).

\section{RESULTS AND DISCUSSION \\ Results of Unit Root Test}


This paper employs Augmented Dickey-Fuller (ADF) and Phillips-Perron (PP) to analyse unit root tests. The purpose of employing the unit root tests is to determine the existence of stochastic non-stationary in the series. All the variables in this study are tested based on "no trend and constant," and "trend and constant." The results of the unit root tests are shown in Table 1. Based on table, the outcomes from the unit root tests of ADF and PP explain that the data are stationary mixture $\mathrm{I}(0)$ and $\mathrm{I}(1)$, and no I(2). Therefore, the ARDL modelling approach can be used in the estimation of BEER model.

Table 1. Results of ADF and PP unit root tests

\begin{tabular}{|c|c|c|c|c|}
\hline \multirow{2}{*}{ Variables } & \multicolumn{2}{|c|}{ ADF } & \multicolumn{2}{|c|}{ PP } \\
\hline & No Trend & Trend & No Trend & Trend \\
\hline \multicolumn{5}{|c|}{ Level } \\
\hline LRER & -1.447 & -2.113 & -1.447 & -2.286 \\
\hline LDPROD & $-3.366 * *(0)$ & -2.596 & $-3.135 * *(3)$ & $-3.358 *(3)$ \\
\hline LNFA & -0.525 & -2.746 & -0.390 & -2.662 \\
\hline LGOVS & -1.962 & -2.098 & -1.862 & -1.999 \\
\hline LTOT & $-3.267 * *(1)$ & $-3.231 *(1)$ & $-3.136 * *(1)$ & -3.120 \\
\hline LOPEN & -0.961 & -0.930 & -0.960 & -1.042 \\
\hline LRID & $-4.849 * * *(0)$ & $-4.494 * * *(0)$ & $-6.473 * * *(9)$ & $-5.88 * * *(10)$ \\
\hline \multicolumn{5}{|c|}{ First Difference } \\
\hline LRER & $-5.042 * * *(0)$ & $-4.986 * * *(0)$ & $-4.969 * * *(5)$ & $-4.915^{* * *}(5)$ \\
\hline LDPROD & $-6.502 * * *(0)$ & $-6.705 * * *(0)$ & $-6.470 * * *(2)$ & $-6.704 * * *(1)$ \\
\hline LNFA & $-6.234 * * *(0)$ & $-6.152 * * *(0)$ & $-7.010 * * *(15)$ & $-6.847 * * *(15)$ \\
\hline LGOVS & $-7.774 * * *(0)$ & $-4.292 * * *(2)$ & $-8.206 * * *(5)$ & $-8.539 * * *(7)$ \\
\hline LTOT & $-6.294 * * *(0)$ & $-6.207 * * *(0)$ & $-6.318 * * *(3)$ & $-6.220 * * *(3)$ \\
\hline LOPEN & $-5.801 * * *(0)$ & $-5.797 * * *(0)$ & $-5.805 * * *(1)$ & $-5.771 * * *(2)$ \\
\hline LRID & $-7.976 * * *(1)$ & $-7.995 * * *(1)$ & $-8.200 * * *(2)$ & $-8.819 * * *(2)$ \\
\hline
\end{tabular}

Notes: The value in parentheses (...) represent the automatic bandwidth selected based on Newey-West method using Bartlett kernel. The ***,**,* indicate the statistically significant level at $1 \%, 5 \%$ and $10 \%$. LER - real exchange rate, LDPROD - productivity differential, LNFA - net foreign assets, LGOVS - government spending, LTOT - terms of trade, LOPEN - trade liberalization (proxy of openness) and LRID - real interest differential. All variables are in logarithm.

\section{Results of Cointegration Test}

The ARDL bound test is used in order to determine the existence of long-term cointegration between the exchange rate and macroeconomics variables in this paper. Table 2 presents the empirical result of bound test for BEER model and the lag length for these regressions was automatically selected based on Schwarz Bayesian Criterion (SBC). The result of bound test shows that the F-statistics for BEER model fall above the upper bound critical value at $10 \%$ significance level and this result suggest that cointegration exists among the variables in the model under investigation.

Table 2. Cointegration bound test analysis

\begin{tabular}{|c|c|c|c|}
\hline \multirow{2}{*}{ F-Statistic } & $\%$ & \multicolumn{2}{|c|}{ BEER Model } \\
\cline { 3 - 4 } & & Lower Bound & Upper Bound \\
\hline F-statistic (Narayan, & 90 & 2.334 & 3.515 \\
2004) & 95 & 2.794 & 4.148 \\
\hline Computed F-statistic & \multicolumn{3}{|c|}{$\mathrm{F}=3.5676^{*}$} \\
\hline
\end{tabular}


Notes: $* *$ and $*$ indicate the statistically significant level at $5 \%$ and $10 \%$. In Narayan (2004), critical values are tabulated for a sample size ranging from 30 to 80 observations.

\section{Results of Diagnostic Tests}

The validity of the ARDL model has been ascertained by a battery of tests, which includes serial correlation LM test, functional form RESET test for the existent of specification error in the model, JarqueBera normality test on the residual and ARCH test for heteroscedasticity. Generally, the diagnostic tests for BEER model in Malaysia produce good results. Table 3 clearly indicates that the model is free from serial correlation and heteroscedasticity, whilst the functional form indicates that there are no specification errors and normally distributed.

Table 3. Results of diagnostic tests for ARDL.

\begin{tabular}{|c|c|}
\hline Diagnostic Checking & P-Value \\
\hline Serial correlation & 0.643 \\
Functional form & 0.821 \\
Normality & 0.557 \\
Heteroscedasticity & 0.151 \\
\hline
\end{tabular}

Note: ARDL $(1,0,1,0,1,1,0)$ was automatic selected on the basis of Schwarz Bayesian Criterion (SBC).

\section{Estimates of Long-Run Model}

The next discussion is based on results of 'unrestricted error correction model' (UECM-ARDL), which is employed in order to estimate the long-run coefficient of exchange rate model. The results based on Table 4 shows that the estimated orders for BEER model is $\operatorname{ARDL}(1,0,1,0,1,1,0)$ and the optimal lag length was automatically selected on the basis Schwarz Bayesian Criterion (SBC). The results clearly indicates that $\angle D P R O D^{\prime}$ ENFA' ETOT and ${ }^{2}$ OPEN are statistically significant, at least at $10 \%$ significant level. The long-run model explains that the higher level of productivity differential and net foreign assets could lead to depreciation in the exchange rates in Malaysia. However, the negative impacts of the productivity differential and net foreign assets are not compatible with the explanation of theoretical predictions. According to Devereux (1999), the increase in productivity growth in the tradable sector feeds through into national distribution services and will cause real exchange rate to depreciate. This study suggests that growth in manufacturing productivity in Asian countries including Malaysia has been mirrored by growth in the national distribution system. If this truly happens, the growth that is due to productivity increases in traded goods may lead to continuous reduction in prices of traded goods. Therefore, the improvement in productivity in traded goods causes the real exchange rate to depreciate. Whilst, study conducted by Égert et al. (2004) stated that the developing countries tend to finance their growth through foreign capital in the medium term. Hence, the real exchange rate will experience appreciation during this phase due to strong capital inflow. However, these countries began servicing their debt when foreign liabilities position was attained in the long term. Therefore, the increase in net foreign liabilities causes the real exchange rate to depreciate.

Besides that, the positive impact of terms of trade on exchange rate explains that income effects dominate the substitution effects. The increasing in terms of trade leads to reduction in the cost of imported inputs thus shifting away imports demand. Therefore, the improvement in terms of trade have resulted in exchange rate appreciation (Naseem et al., 2008). Whilst, the positive impact on trade liberalization (proxy by openness) implies that reduction of tariff and non-tariff protection increases the level of trade in the current account, therefore the exchange rate appreciated (Balázs \& Amina, 2003; Coulibaly \& Gnimassoun, 2013).

Table 4. Results of long-run coefficient

\begin{tabular}{|l|c|c|c|c|}
\hline \multirow{2}{*}{ Variables } & Expected Sign & \multicolumn{3}{|c|}{ ARDL(1,0,1,0,1,1,0) } \\
\cline { 2 - 4 } & & Coefficient & S. E. & t-Stat \\
\hline
\end{tabular}


The Turkish Online Journal of Design, Art and Communication - TOJDAC

ISSN: 2146-5193, September 2018 Special Edition, p.905-917

\begin{tabular}{|c|c|c|c|c|}
\hline LDPROD & + & -3.083 & 1.300 & $-2.372^{* *}$ \\
LNFA & + & -0.532 & 0.296 & $-1.796^{*}$ \\
LGOVS & - & 0.371 & 0.919 & 0.403 \\
LTOT & +- & 2.750 & 1.085 & $2.534^{* *}$ \\
LOPEN & +- & 4.278 & 1.413 & $3.027^{* * *}$ \\
LRID & + & 0.165 & 0.197 & 0.836 \\
C & & -16.708 & 3.691 & $-4.53 * * *$ \\
\hline
\end{tabular}

Notes: Asterisk $* * *, * *$ and $*$ denotes statistically significance at $1 \%, 5 \%$ and $10 \%$ respectively. LDPROD - productivity differential, LNFA - net foreign assets, LGOVS - government spending, LTOT - terms of trade, LOPEN - trade liberalization (proxy of openness) and LRID - real interest rate differential. C is intercept. All variables are in Logarithm.

\section{Estimates of Error Correction Model (ECM)}

Table 5 shows the results of short-run coefficient based on Restricted Error Correction Model (RECMARDL). According to Engle and Granger (1987), the error correction model (ECM) is the short-run model with long-run information. If the ECM is negative and significant, therefore this implies that independent variable Granger causes dependent variable and is cointegrated. As shown in Table 5, the error correction term for BEER model is significant and carries the expected negative sign. This indicates that the model is stable and any deviation from equilibrium will be corrected in the long run. The coefficient of error correction term implies the speed of adjustment process. Based on the result, the coefficient of the error correction term indicates that $54 \%$ of the previous year's shocks adjust back to long-term equilibrium in the current year. This result provides further evidence of the existence of a stable long-run relationship among the variables in the exchange rate model. Furthermore, the results reveal consistency with the bound test analysis for BEER model.

Table 5. Results of short-run coefficient and error correction model (ECM)

\begin{tabular}{|c|c|c|c|}
\hline Variables & Coefficient & S. E. & t-Stat \\
\hline $\begin{array}{c}\Delta \text { LDPROD } \\
\Delta \text { LNFA } \\
\Delta \text { LGOVS } \\
\Delta \text { LTOT } \\
\Delta \text { LOPEN } \\
\Delta \text { LRID } \\
\Delta \mathrm{C} \\
\text { ECM }(-1)\end{array}$ & $\begin{array}{c}-1.660 \\
0.190 \\
0.200 \\
0.113 \\
0.795 \\
0.089 \\
-8.995 \\
-0.538\end{array}$ & $\begin{array}{l}1.272 \\
0.125 \\
0.544 \\
0.596 \\
1.173 \\
0.092 \\
4.046 \\
0.261\end{array}$ & $\begin{array}{c}-1.305 \\
1.519 \\
0.367 \\
0.189 \\
0.678 \\
0.968 \\
-2.223^{* *} \\
-2.064^{*}\end{array}$ \\
\hline \multicolumn{2}{|c|}{$\mathrm{R}^{2}=0.74$} & \multicolumn{2}{|c|}{$\mathrm{SER}=0.100$} \\
\hline
\end{tabular}

Notes: Asterisk $* * *, * *$ and $*$ denotes statistically significance at $1 \%, 5 \%$ and $10 \%$, respectively. LDPROD - productivity differential, LNFA - net foreign assets, LGOVS - government spending, LTOT - terms of trade, LOPEN - trade liberalization (proxy of openness), and LRID - real interest rate differential. C is intercept. All variables are in Logarithm.

In turn, Figure 3 illustrates that the plot of the statistics from the CUSUM and CUSUMSQ remain within the critical bounds at 5\% significance level, thus explaining that all coefficients in the error correction model are stable over time. This evidence shows that the selected model adopted in this study seem to be good in estimating the long-run and short-run cointegration between exchange rate and macroeconomic variables in Malaysia. 

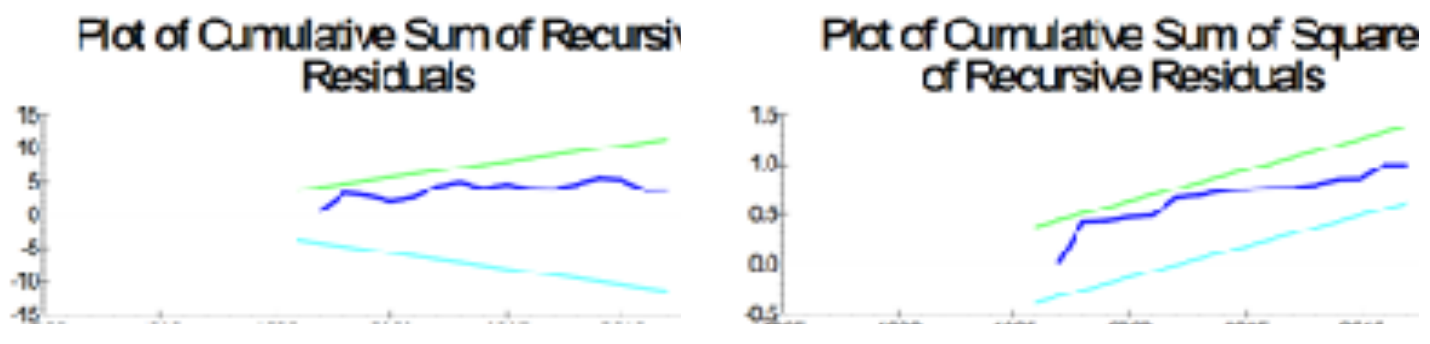

Figure 3. CUSUM and CUSUMSQ (Note: The straight lines represents critical bounds at $5 \%$ significant level)

\section{Misalignment of Exchange Rate of Ringgit Malaysia}

This section presents the results of misalignment of exchange rate for Malaysia based on BEER model. Holtemöller and Mallick (2013) stated that misalignment occurs in markets where actual exchange rate does not respond adequately to changes in economic fundamentals. Table 6 shows the percentage of the misalignment in exchange rate, whilst Figure 4 shows the plot of residuals and two standard error bands. The figures in Table 6 demonstrate the movements of the disequilibrium exchange rate (or misalignment). It implies that a currency would experience undervaluation if the disequilibrium is above zero and overvaluation if the disequilibrium is below zero. Figure 4 shows that Malaysia has experienced a small misalignment of exchange rate, where the movement of the residuals is within the bound. This finding is exactly consistent with study conducted by Lee (2005).

Table 6. Misalignment of exchange rate in Malaysia, 1985-2012

\begin{tabular}{|c|c|c|c|}
\hline Year & $\mathbf{\%}$ & Year & $\mathbf{\%}$ \\
\hline 1985 & -0.09 & 1999 & -0.04 \\
1986 & 0.07 & 2000 & -0.06 \\
1987 & -0.02 & 2001 & -0.01 \\
1988 & -0.03 & 2002 & 0.03 \\
1989 & 0.04 & 2003 & 0.08 \\
1990 & 0.04 & 2004 & -0.02 \\
1991 & 0.12 & 2005 & 0.06 \\
1992 & -0.11 & 2006 & -0.05 \\
1993 & -0.12 & 2007 & -0.07 \\
1994 & 0.06 & 2008 & 0.02 \\
1995 & -0.04 & 2009 & 0.10 \\
1996 & -0.14 & 2010 & 0.02 \\
1997 & 0.14 & 2011 & -0.11 \\
1998 & 0.12 & 2012 & 0.01 \\
\hline
\end{tabular}

Notes: Figures are exchange rate misalignments in percentage (\%). Positive (negative) value for residual denotes an undervaluation (overvaluation).

\section{Plot of Residuals and Two Standa Error Barnds}

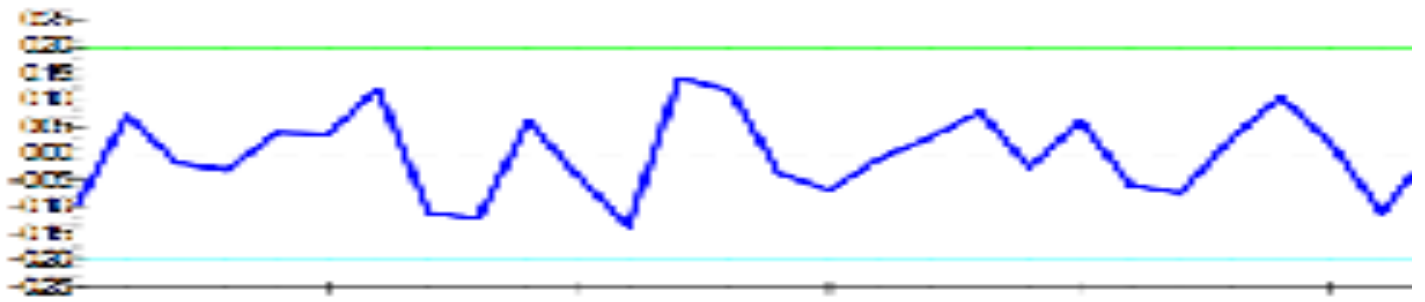

Figure 4. Residuals and two standard error bands for BEER model (Notes: The movements of the residuals above zero (positive value) are associated with undervalued exchange rate, whilst below zero (negative value) are associated with overvalued exchange rate.) 
In turn, this study also produces the predictive power of the model. The model's forecasts with small root mean squared errors (RMSE) imply the evidences of the goodness of fit and it can be showed graphically in Figure 5. Generally, the result shows that BEER model has a small RMSE for In-Sample dynamic forecasting errors. This reveals that BEER model is likely fit the data very close throughout the period and track the actual exchange rate to get a considerable number of turning points correct. However, the previous study conducted by Shukri et al. (2017) shows that the RMSE for fundamental equilibrium exchange rate (FEER) model is smallest than BEER model in this studies, thereby explaining that the FEER model is marginally a better model than BEER model for Malaysia.
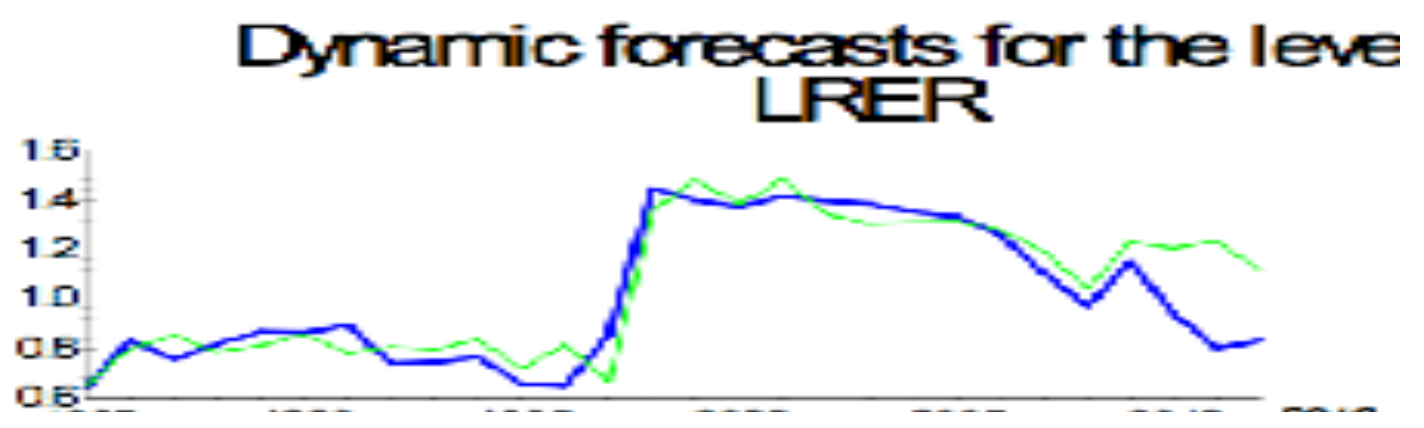

Figure 5. The plots of the real exchange rate and the predicted real exchange rate (Dynamic forecasts

\section{CONCLUSION}

root mean squared error $=0.080$ )

The general objective of this study is to investigate the exchange rate behavior using BEER model. By adopting the ARDL modeling, this study is able to make correct analysis of the short-run and long-run cointegration between exchange rate and macroeconomic variables. The empirical evidence shows that productivity differential, net foreign assets, terms of trade and trade liberalization (proxy by openness) plays important roles in influencing exchange rate behavior in Malaysia. It also shows that the disequilibrium for Ringgit Malaysia is quite small and stable (see Table 6 and Figure 4). The policy implications of this study are suggested as follow. Firstly, the long-run and short-run relationship between exchange rate and macroeconomic variables in BEER model shows that there is statistically significant link between dependent and independent variables. This suggests that the exchange rate in Malaysia is driven by macroeconomic variables. Therefore, it is important for the policy makers, investors, bankers, exporters-importers and researchers to take into account about the macroeconomic indicators in investigating the exchange rate movements. Secondly, the misalignment of exchange rate reveals whether the exchange rate is overvalued or undervalued. Rodrik (2008) reported that overvaluation of exchange rate will negatively impact economic growth due to fall in exports, while undervaluation of exchange rate positively impacts economic growth and encourages exports. Therefore, policy makers need to avoid exchange rate overvaluation by introducing better policy instruments. For instance, policy makers need to increase import tariff to reduce import demand and/or introduce export subsidies to enhance export demand.

\section{REFERENCES}

Balázs, É., \& Amina, L. R. (2003). Estimating the equilibrium exchange rate of the Central and Eastern European acceding countries: The challenge of Euro adoption. Review of World Economics, 139(4), 683-708.

Bénassy-Quéré, A., Lahrèche-Révil, A., \& Mignon, V. (2011). World-consistent equilibrium exchange rates. Journal of the Japanese and International Economies, 25(2), 12-32.

Berger, T., \& Kempa, B. (2012). Taylor rules and the Canadian-US equilibrium exchange rate. Journal of International Money and Finance, 31(5), 1060-1075.

Chin, L. (2005). The monetary approach to exchange rate determination in five ASEAN countries. PhD thesis, Universiti Putra Malaysia.

Chin, L., Azali, M., Yusop, Z. B., \& Yusoff, M. B. (2007). The monetary model of exchange rate: Evidence from The Philippines. Applied Economics Letters, 14(13), 993-997.

Chin, L., Habibullah, M. S., \& Azali, M. (2009). Tests of different monetary aggregates for the monetary models of the exchange rate in five ASEAN countries. Applied Economics, 41(14), 1771-1783.

Clark, P. B., \& MacDonald, R. (1999). Exchange rates and economic fundamentals: A methodological comparison of BEERs and FEERs. In Equilibrium Exchange Rates. Springer, pp. 285-322. 
Cline, W. R., \& Williamson, J. (2008). Estimates of the equilibrium exchange rate of the Renminbi: Is there a consensus and, if not, why not? In Debating China's Exchange Rate Policy. Peterson Institute, pp. 131-154.

Corsetti, G., Pesenti, P., \& Roubini, N. (1999). What caused the Asian currency and financial crisis? Japan and the World Economy, 11(3), 305-373.

Coudert, V., \& Couharde, C. (2007). Real equilibrium exchange rate in China is the Renminbi undervalued? Journal of Asian Economics, 18(4), 568-594.

Coulibaly, I., \& Gnimassoun, B. (2013). Optimality of a monetary union: New evidence from exchange rate misalignments in West Africa. Economic Modelling, 32, 463-482.

Daniel, J. P., \& VanHoose, D. D. (2005). International monetary and financial economics. Pearson.

Devereux, M. B. (1999). Real exchange rate trends and growth: A model of East Asia. Review of International Economics, 7(3), 509-521.

Driver, R. L., \& Westaway, P. F. (2013). Concepts of equilibrium exchange rates. In Exchange Rates, Capital Flows and Policy. Routledge, pp. 98-148.

Engle, R. F., \& Granger, C. W. (1987). Co-integration and error correction: Representation, estimation, and testing. Econometrica: Journal of the Econometric Society, 251-276.

Egert, B., Halpern, L., \& MacDonald, R. (2006). Equilibrium exchange rates in transition economies: Taking stock of the issues. Journal of Economic Surveys, 20(2), 257-324.

Égert, B., Lahreche-Revil, A., Lommatzsch, K. (2004). The stock-flow approach to the real exchange rate of CEE transition economies. In CEPII Working Paper No. 2004 - 15, pp. 1-42.

Habibullah, M. S. (1999). Divisia monetary aggregates and economic activities in Asian developing economies. Ashgate Publishing.

Hendry, D. F., \& Clements, M. P. (2003). Economic forecasting: Some lessons from recent research. Economic Modelling, 20(2), 301-329.

Holtemöller, O., \& Mallick, S. (2013). Exchange rate regime, real misalignment and currency crises. Economic Modelling, 34, 5-14.

Keblowski, P., \& Welfe, A. (2010). Estimation of the equilibrium exchange rate: The CHEER approach. Journal of International Money and Finance, 29(7), 1385-1397.

Koske, I. (2008). Assessing the equilibrium exchange rate of the Malaysian ringgit: A comparison of alternative approaches. Asian Economic Journal, 22(2), 179-208.

Lee, C. (2005). Exchange rate misalignments in ASEAN-5 countries. Labuan Bulletin of International Business and Finance, 3(1), 11-31.

López-Villavicencio, A. (2006). Real equilibrium exchange rates: A panel data approach for advanced and emerging economies. Économie Internationale, (4), 59-81.

MacDonald, R. (1999). What determines real exchange rates? The long and the short of it. In Equilibrium Exchange Rates. Springer, pp. 241-284.

Maeso-Fernandez, F., Osbat, C., \& Schnatz, B. (2006). Towards the estimation of equilibrium exchange rates for transition economies: Methodological issues and a panel cointegration perspective. Journal of Comparative Economics, 34(3), 499-517.

Meese, R. A., \& Rogoff, K. (1981). Empirical exchange rate models of the seventies: Do they fit out of sample? Journal of International Economics, 14(1-2), 3-24.

Mohd Sidek, N. Z., \& Yusoff, M. (2009). An empirical analysis of Malaysian Ringgit Equilibrium exchange rate and misalignment. Global Economy and Finance Journal, 2(2), 104-126.

Narayan, P. (2004). Reformulating critical values for the bounds F-statistics approach to cointegration: An application to the tourism demand model for Fiji. Monash University Naseem, N. A. M., Tan, H. B., \& Hamizah, M. S. (2008). Exchange rate misalignment, volatility and import flows in Malaysia. International Journal of Economics and Management, 1(3), 130-150.

Pattichis, C., Maratheftis, M., \& Zenios, S. A. (2007). Is the Cyprus pound real effective exchange rate misaligned? A BEER approach. International Economic Journal, 21(1), 133-154.

Pesaran, M. H., Shin, Y., \& Smith, R. J. (2001). Bounds testing approaches to the analysis of level relationships. Journal of Applied Econometrics, 16(3), 289-326.

Rodrik, D. (2008). The real exchange rate and economic growth. In Brookings Papers on Economic Activity, pp. 365-412.

Sahminan. (2005). Estimating equilibrium real exchange rates of the Rupiah. In Working Paper WP/08/2005, Bank Indonesia.

Shukri, J. M., Habibullah, M. S., \& Sanusi, N. A. (2017). The estimation of equilibrium exchange rates in Malaysia: Evidence using FEER model. Advanced Science Letters, 23(9), 8492-8497.

Tsen Wong, H. (2013). Real exchange rate misalignment and economic growth in Malaysia. Journal of Economic Studies, 40(3), 298-313.

You, K., \& Sarantis, N. (2008). The equilibrium real effective exchange rate of China: A NATREX approach. Centre for International Capital Markets Discussion Papers, 2008(15), 1-50.

Submit Date: 05.07. 2018, Acceptance Date: 28.08.2018, DOI NO: 10.7456/1080SSE/126

Research Article - This article was checked by Turnitin

Copyright (C) The Turkish Online Journal of Design, Art and Communication 